Article

\title{
Information Sharing Strategies in the Social Media Era: The Perspective of Financial Performance and CSR in the Food Industry
}

\author{
Magdalena Mądra-Sawicka ${ }^{1, *(1)}$ and Joanna Paliszkiewicz ${ }^{2}$ (D) \\ 1 Institute of Economics and Finance, Warsaw University of Life Sciences-SGGW, 02-787 Warsaw, Poland \\ 2 Institute of Management, Warsaw University of Life Sciences-SGGW, 02-787 Warsaw, Poland; \\ joanna_paliszkiewicz@sggw.edu.pl \\ * Correspondence: magdalena_madra@sggw.edu.pl; Tel.: +48-225934242
}

Received: 31 August 2020; Accepted: 27 September 2020; Published: 29 September 2020

check for updates

\begin{abstract}
This paper aims to identify financial measures that are related to Corporate Social Responsibility (CSR) involvement activities. The study concerns the food industry, in which clients, as well as stakeholders, increasingly appreciate socially responsible companies, which could be a crucial factor for future growth strategy. An analysis was made on a sample of 448 food companies from 50 countries in 2009-2020. As a financial measure for CSR assessment, we used profitability ratios, dividend payout ratio, price-to-earnings ratio and market capitalization. The results confirmed that CSR reporting was a crucial division that differentiated companies from the perspective of profitability, OE, market capitalization, and share price. The CSR practices that are realized and published in reports become an important signal for investors that the company has a good financial situation and is able to invest in CSR without reducing its performance.
\end{abstract}

Keywords: CSR reporting; financial performance; food industry; information sharing

\section{Introduction}

The issue of sharing information about companies' activity points to different strategies that are implemented. Each of these strategies is joined with social media as a direct channel of companies' activities. Corporate Social Responsibility (CSR) communication is using social media as one of the key channels to share information with stakeholders to report efforts and initiatives of the company [1]. CSR campaigns use social media to present their social responsibility [2]. CSR sustainability reports enhance the reputation of businesses and organizations [3]. An annual report about CSR activity provides a specific signal for investors. Thus, this issue is related to signaling theory. These signals are expected to be positively received and are reflected in a market price increase. Investors will receive more information due to CSR activities presentation. CSR could also be perceived to be a signal for investors about the quality of management [4].

According to Ratajczak, consumers pay more attention to the aspect of responsible practices in the agriculture sector [5] and concern the environmental impact of companies' operation. Consumers are increasingly looking for information about producers, products, and the supply chain. This approach reveals that CSR policy affects the agri-food processes or the product [6]. A passive approach to ecological problems initiated the stimulation of consumer activity that could be crucial in the food industry [7]. Therefore, the food industry is an industry with a sizeable ecological potential that is mostly untapped. Thus, some industries are more sensitive than others to social practices and their environmental impact [8]. Food industry CSR issues are also related to food safety and biotechnology supported by powerful stakeholder groups $[9,10]$. The food industry noticed a growth of CSR 
initiatives [11], and as a result, we experience new forms of CSR communication through different social media platforms [12]. It results in higher awareness of potential consumers that could be interested in CSR food companies initiatives [13].

The research aimed to assess the relationship between CSR reports and the financial achievements of food industry companies. The research period covered the years 2009-2020 when the reports were published. The study concerns recommendations for stakeholders. The conducted study contributes to the current state of the art concerning the CSR relationship with companies' financial performance among specific food sector international analyses. The contribution of the study concerns filling the gap of companies' food industry characteristics that impact on the CSR strategy construct. The study is based on stakeholder theory that approaches bigger firms that are listed on the stock exchange. Two research questions were addressed in the study:

RQ1: Is there a difference among companies' financial performance (Return on Assets (ROA), Return on Equity (ROE), dividend payout ratio, Price-to-earnings ratio (P/E), and market capitalization) according to declare in CSR reports activities?

RQ2: Which financial performance measures have a positive relation with CSR company's activities?

This paper is organized as follows. The literature review reveals issues related to CSR engagement and financial performance. Next, the methods and sample characteristics are explained and followed by the research results. Subsequently, the discussion, conclusions, and limitations of the study, as well as future directions, are presented.

\section{Literature Review}

\subsection{Company Social Responsibility Role in Business}

The concept of Corporate Social Responsibility (CSR) is widely discussed in the literature and business practices. It covers many different aims to support companies' activities. Shelton proposed the CSR concept in 1924; then, it was later developed in 1950 by Bowen by following significant value for society. From 1970, the CSR scope of research was expanded in many fields. CSR is a way of running a business taking into account specific spheres of the company's influence such as the social and ecological spheres. CSR goes beyond the direct business interests of the company and legal regulations, pointing to the voluntary nature of the initiatives taken. The development of the CSR idea refers to Freeman's theory, according to which the company's activity is influenced by many stakeholders, such as shareholders, employees, residents forming the local community, authorities, suppliers, clients, or investors [14].

The main benefits are related to improving the image and relations with the environment by CSR practices that ensure the acceptance of stakeholders and weaken the negative consequences of possible future crises situations. Socially engaged enterprises attract investors who perceive these entities as more stable and reliable, guaranteeing investment security, which contributes to an increase in the prices of their shares. A strong financial position on stock leads to greater companies' investment expenses in aspects of CSR [15]. On the other hand, CSR activities are sometimes perceived as superficial measures inconsistent with the company's strategy. The second point of view underlines that CSR is no longer an arbitrary choice of a company. It becomes an essential requirement for the food industry [16]. However, CSR practices are often perceived as an obligation only of profitable companies [17], even though researchers noticed that CSR engagement is not based merely on financial performance [18]; however, it still creates the ground of capital access for it.

\subsection{CSR Reporting as a Channel for Information Sharing}

Financial statements and financial reports do not contain information about CSR activities; a dedicated CSR report can make stakeholders more aware [19]. Companies that properly communicate their socially responsible activities achieve higher prices on the financial market [20]. However, CSR activity can be differently assessed in different financial markets due to less developed information 
channels [21] and institutional surroundings [22]. From the practice perspective, the information sharing through CSR could be divided into four main areas: reporting, accounting, CSR versus financial results, and impact of CSR strategy on company value.

As a form of reporting by a company, a social responsibility strategy is mostly motivated by the practice adopted among the leading competitors [23]. Another factor that determines the CSR activities are related to the company size, stakeholders' requirements, industry trends, or geographical area [23]. The impact of CSR reporting on financial performance is related to the implementation of the fundamental aim related to profits maximization or market-share increase. The results of the research in the literature do not recognize the reporting of social responsibility as a positive or negative determinant of company financial performance. It is mostly due to the higher cost that could lead temporarily to a competitive disadvantage [24,25]. Thus, the urgent issue for the food industry is the creation of a strategy that will allow companies to fulfill the CSR to society and keep the reducing cost trend due to better work efficiency [26].

The other side of research underlines the benefits that the company can compensate with higher productivity due to better quality of work $[27,28]$. The effects of CSR activities may bring noticeable results in the form of increased sales, improved functioning of the company, or enhanced image of the company and its products, as well as greater satisfaction for employees and their families. The creation of a CSR company image in the community is increasing employee morale [29]. Showing CSR in annual reports could result in high returns on assets, equity, and earnings per share [30]. CSR company activities signal the organizational attractiveness of a company for potential job-seekers [31].

Client satisfaction is one of the leading factors of CSR implementation and development. Another aspect of the issue is related to providing reliable information about products or services that are offered by the company. Thus, CSR activities appear to make a positive impact on customer satisfaction and company value [32]. However, this effect could be visible in the long-run perspective [33]. CSR practices of companies in the food sector could affect market visibility and positively impact financial results. CRS reporting is also helpful for stakeholders to evaluate the companies' activities and could become a part of a business strategy. The CSR concept and regulation are more applied in developed economies [29].

\subsection{CSR Reporting and Financial Performance}

The interlinkages between finance and CSR from a microeconomic side are influenced by the impact of stakeholder and responsible investment that could create corporate behavior [34]. The financial performance of the company affects the social, ethical, and environmental behavior of the firm. Thus, financial performance is broadly constructed in CSR research. Financial performance is defined in CSR as recognized benefits according to increased revenue, profit, and growth rates [35]. The commonly used company financial performance (CFP) indicators are mostly grouped into three areas: accounting-based (ROA, ROE, Return on sale (ROS), net operating income, net income), market-based (stock returns, market value, change in stock return) and mixed: both accounting and market-based (Tobin's $Q$ and market value-added measure) [36].

Most of the research is based on companies' membership in the CSR index [37]. Another approach is related to specific indexes such as the KLD index, which is based on eight areas of company performance that present the multidimensions of CSR activity recognition. More and more research is associated with the CSR evaluation framework based on a higher number of different CSR dimensions [38] to underline the broad range of CRS practices. Elsayed and Paton developed this direction of research and distinguished the multiple-indicators, multiple-causes (MIMIC) model [39]. Other analyses are based on CSR content analysis and questionnaire surveys. This method includes researchers self-selecting the CSR dimensions [36].

In the short term, CSR expenses may have a negative impact on financial results due to the delay in the benefits of the implemented activities over time. According to Karnani, CSR activities increase costs without maintaining the corresponding benefits [40]. However, the relation between CSR and financial 
performance could be mutually beneficial as well as complex. Thus, better financial determinants of CSR investment understanding is important [41].

A positive relationship between CSR and the company's financial results is evident in many studies [41-46]. The relations of CFP and CSR were also assessed as positive by Rogers, Choy, and Guiral [47], as they include the company's innovation effort. Oeyono, Samy, and Bampton found a positive relationship between CSR and profitability in the case of companies from emerging markets, which reveals that the reporting of social activities brings benefits [48]. The meta-analysis conducted by Wang, Dou, and Jia underlines that the effect size of the CSR-CFP relationship is positive and significant. This relation is stronger for companies from advanced economies than for firms from developing economies [49]. Wang, Choi, and Li noticed an inverted U-shaped relationship between CSR and CFP, which supports the idea of an optimal level of CSR company engagement [50].

The difference among conducted studies is related to companies' investment in intangible assets $[4,47,51]$. Another side of the problem is the size of the company's CSR commitment. Low social commitment has a positive effect on the financial consequences of companies in the short term [52]. Many studies results declare no direct link between corporate responsibility and financial performance [53].

\subsection{Corporate Social Responsibility Disclosure}

Corporate Social Responsibility Disclosure (CSRD) is the practice of presenting disclosures of company corporate social responsibility. These disclosures are related to annual reports, the main part of which is the financial statements of companies, or to separate CSR reports, such as social reports, sustainable development reports, corporate responsibility reports, sustainable and responsible business reports, or integrated reports. Corporate disclosure helps spread information among stakeholders and investors on the capital market, and it also supports the evaluation of other measures [54].

From the information asymmetry perspective, institutional investors may prefer companies that report their CSR activities broadly. CSR reduces the uncertainty of companies' future cash flows and explores business opportunities [22]. However, stakeholder relationships and agency conflicts differ between industries [22]. Thus, the information asymmetry will not be a direct issue of the conducted study due to the analysis of one sector. The previous research reveals that the relationship between CSR and dividend policy is statistically significant [55] due to dividend playing a substantial role as a signal for investors [56]. Positive relations between CSR and financial performance are related to consumer interference, which suggests that the company is responsible for its product and services. In addition, the signaling theory supports positive relations by reducing information asymmetry. Social identity theory also impacts this relation. Thus, the consumer is more interested in identifying themself with socially responsible companies [57]. This identification encourages positive evaluations of a company product [58] and increases the consumer's loyalty and satisfaction [6].

\section{Materials, Methods, and Sample}

\subsection{Material}

The study uses firm-level panel data. The sample consists of companies from the Thomson Reuters Food and Beverages index, which includes the biggest companies in the world. This index consists of companies according to weighted market capitalization. This selection contains companies that are more prone to realized CSR strategy; thus, they are operating globally. Bigger companies with high capital intensity emphasize greater product differentiation, operate in high growth markets, and are more prone to invest in CSR [35]. The research period covered the years 2009-2020. We use a two-step level of selecting the data to enhance the data quality. In the first step, we select companies from the Food and Beverage Index and in the second step, we erase all duplicate records and those without any financial measures. The minimal number of records for each company was two years and a maximum of 12 years. The investigated period was limited by a number of observations that enabled the establishment of a logit panel model. The study was conducted among 50 European countries 
of a sample of 448 companies and 4493 observations. The following countries were representing investigated companies: Argentina (1), Australia (18), Austria (1), Belgium (3), Brazil (9), Canada (11), Cayman Islands (1), Chile (5), China (15), Czech Republic (2), Denmark (5), Egypt (3), Faroe Islands (1), Finland (3), France (5), Germany (1), Hong Kong (13), India (26), Indonesia (17), Ireland (5), Israel (3), Italy (1), Japan (64), Jersey (1), Korea (29), Kuwait (1), Malaysia (22), Mexico (9), Morocco (2), Netherlands (3), New Zealand (7), Norway (8), Oman (1), Pakistan (2), Philippines (5), Qatar (2), Saudi Arabia (6), Singapore (7), South Africa (6), Spain (1), Sweden (8), Switzerland (8), Taiwan (13), Thailand (10), Turkey (3), Ukraine (1), United Arab Emirates (2), United Kingdom (12), United States of America (58), and Vietnam (8).

The conducted studies do not include the detailed structure of CSR reporting, but they assess the fact that this kind of report is being published. Two types of reports were considered: CSR Sustainability Reporting and CSR Sustainability Reporting Global Activities. In the case of the first type of report, only $28.1 \%$ of observations published it; for the second, it was $28.2 \%$.

The sample was divided into two groups: non-CSR companies and CSR companies. We include the companies to the group according to CSR reports availability. A similar approach was adopted by Maggina et al. [59] and Dumitrescu and Simionescu [60]. The average age of the firm in the non-CSR group is 40, while in the CSR group, it is 47 . Companies that operate longer are more determined to introduce CSR practices. It underlines the results of studies obtained by other researchers that older companies invest more in CSR [61,62]. Most (81.2\%) of the companies were operating in the manufacturing sector.

\subsection{Methods}

In the study, the descriptive statistics show the characteristic of financial variables. The Mann-Whitney U-test application was made for the verification of CSR and a non-CSR group of companies. This test was used for investigating differences between the highlighted groups and relies on ranking the results of a dependent variable (one of five financial measures).

The financial performance of companies was assessed by five factors such as ROA, ROE, dividend payout ratio, $\mathrm{P} / \mathrm{E}$, and market capitalization. ROA (return on assets) was defined in a study as net income over total assets. ROA is positively correlated with the stock price; a higher ROA implies higher value creation for shareholders [57]. This measure was also used in the studies of Wang et al., Tang et al., and Iqbal et al. [50,63,64]. According to Galant and Cadez, this measure could be varied when different industries are compared [36]. This problem was eliminated in the study due to one industry analysis. ROA implies the profitability based on all assets that the company possesses, while ROE presents the improving of return for stakeholders; thus, it measures net income to total ordinary equity. ROA indicates how companies increase profits and ROE, which is using its capital [65]. This measure is often used in CSR and financial performance relationship recognition. The market value of the CSR companies was mostly investigated by the P/E ratio [44] and capitalization measure [35,59]. The dividend payout is one of the signals for investors about the company's financial situation. According to Benlemlihhe, the dividend policy is more stable for firms with a high CSR score [66]. Investment in CSR and expected dividends are related mostly due to the profitability channel [67]. Thus, in a different situation, companies can invest more in CSR and reduce the dividend payment, and vice versa. The adopted strategy may depend on the expectations of stakeholders

The next step of analysis concerns the qualitative approach that was used for this study using a logistic regression panel model with a binary dependent variable. We used as the dependent variable the binary variable $C S R_{i t}$, which equals 1 if the $i$-th firm publishes a CSR report in the year $t$, and which equals zero when companies did not have this kind of report.

$$
C S R=\left\{\begin{array}{l}
1 \text { if } \operatorname{CSR}>0 \\
0 \text { if } C S R=0
\end{array}\right.
$$


The effects of CSR are noticeable in the long term. In a short time, the impact of individual projects or selected areas can be assessed. Thus, in the study, we include a one-year lagged value for financial measures the effect of CSR publication. The basic regression form of a binary-choice panel model is in Equation (2):

$$
y_{i t}^{*}=\beta x_{i t}+c_{i}+\varepsilon_{i t},
$$

where superscript $i$ represents the $i$-th company,

$t$-denotes time $(t=2009, \ldots, 2020)$,

$\beta$-is the vector of $K$ structural parameters $(K x 1)$,

$\varepsilon_{i t}$-is the vector of disturbance term,

$c_{i}$-is the individual effects,

$x_{i t}$-is the vector of explanatory variables, including the following series:

$$
x_{i t}=\left[R O A_{i t}, R O E_{i t}, D_{I V p a y o u t}{ }_{i t}, P / E_{i t}, \text { MartCap }_{i t}\right]^{\prime}
$$

\section{Results}

Table 1 demonstrates the descriptive statistics of financial performance measures in two groups of companies. Companies that report CSR practices notice a higher level of ROA and ROE. The higher difference in the average ROE (6.78 pp) may result from the fact that the CSR group includes larger, older, and more recognizable enterprises. Empirical findings show that companies that do not invest in CSR activities do not publish CSR reports, even though they have a higher P/E ratio. However, the variation of this measure in this group was very high. It could be related to companies that are already highly assessed by investors (high prices) and do not see a competitive advantage in CSR investment for further growth. It was also stated in Hartmann's research that CSR allows firms to differentiate and enhance food companies' competitiveness [68]. Kong also underlines the positive reaction of the investors on the financial market to the level of CSR in the food industry. According to his research results across food companies, CSR activities are an essential factor impacting investor investment decisions and thus affect the price and bring long-term benefits [69]. However, these companies are not the biggest one on the market. Companies from the CSR group noticed higher market capitalization, which is mostly explained by the fact this group includes enterprises operating globally.

Table 1. Descriptive statistics.

\begin{tabular}{ccccc}
\hline \multirow{2}{*}{ Variables } & \multicolumn{2}{c}{ CSR. } & \multicolumn{2}{c}{ Non-CSR } \\
\cline { 2 - 5 } & Mean & Std. Dev. & Mean & Std. Dev. \\
\hline ROA (\%) & 6.89 & 6.92 & 6.45 & 9.78 \\
ROE (\%) & 18.03 & 49.32 & 11.25 & 50.66 \\
Dividend Payout Ratio (\%) & 52.81 & 125.45 & 82.88 & 1207.84 \\
P/E & 28.13 & 64.08 & 31.88 & 211.91 \\
Mkt Cap (mln EUR) & 7065.3 & $23,842.4$ & 517.1 & 2713.5 \\
\hline
\end{tabular}

The Mann-Whitney U-test results (Table 2) confirmed the significant differences between CSR and non-CSR companies with respect to ROA, ROE, $\mathrm{P} / \mathrm{E}$, and market capitalization. The more robust predictor of group difference was noticed for $\mathrm{ROA}, \mathrm{P} / \mathrm{E}$, and market capitalization. The dividend payout ratio does not differentiate a group of CSR and non-CSR companies significantly. The dividend payment is more often met in companies with a high CSR score [66], which shows different strategies among CSR groups of companies. Thus, this measure is not a key factor for assessing the financial performance in the food industry. It is related to the disappearing dividend trend on capital markets [56]. 
Table 2. Mann-Whitney U-test results between Corporate Social Responsibility (CSR) and non-CSR companies.

\begin{tabular}{cccccc}
\hline Detailed & $\mathbf{U}$ & z-Value & $p$-Value & $\mathbf{N}_{\mathbf{1}}$ & $\mathbf{N}_{\mathbf{2}}$ \\
\hline ROA & $1,294,791$ & -5.6142 & 0.000000 & 2751 & 1066 \\
ROE & $1,403,554$ & -2.0536 & 0.040015 & 2751 & 1066 \\
Dividend Payout Ratio & 935,954 & -0.0479 & 0.961832 & 1950 & 961 \\
P/E & 979,277 & -9.2590 & 0.000000 & 2385 & 1026 \\
Mkt Cap & 687,852 & -23.4090 & 0.000000 & 2546 & 1066 \\
\hline
\end{tabular}

Source: Own elaboration based on Eikon Databased.

At the 5\% significance level, we can confirm the significant positive influence of ROE and ROA as well as market capitalization on the explained variable (Table 3). Market capitalization and profitability measures reflect the size and position of the company in the industry. Current levels of dividend payout ratio and $\mathrm{P} / \mathrm{E}$ do not have a significant influence on CSR involvement. Thus, the negative investor's markets responses that are visible in P/E are related more strongly with the food industry's current situation than CSR reporting. Moreover, in the case of the logit regression, we can also confirm a positive effect of profitability ROA and ROE on CSR engagement. The profit motivation of investors suggests that strength and more financially stable companies participate in CSR activities [69]. A negative relation was noticed in the case of $\mathrm{P} / \mathrm{E}$. This was due to the higher valuation of shares of companies from the non-CSR group; thus, in these companies, the motivation for CSR investment could be weaker.

Table 3. Estimation results for the logit Fixed Effect (FE) model.

\begin{tabular}{ccc}
\hline \multirow{2}{*}{ Detailed } & \multicolumn{2}{c}{ Conditional Fixed-Effects Logistic Regression } \\
\cline { 2 - 3 } & Coefficient & $p$-Value \\
\hline ROA-1 $_{\text {ROE-1 }}$ & 0.0095 & 0.0000 \\
Rividend Payout ratio-1 & 0.0041 & 0.0000 \\
P/E-1 & -0.0001 & 0.2652 \\
MartCap-1 & -0.0056 & 0.8641 \\
Number of observations & 0.0001 & 0.0000 \\
Number of groups & \multicolumn{2}{|}{2432} \\
\hline \multirow{2}{*}{ Number of observations per group } & \multicolumn{3}{c}{$\operatorname{min~2}$} \\
\hline \multirow{2}{*}{$\operatorname{max~12}$} \\
\hline
\end{tabular}

\section{Discussion}

The findings confirm the significant differences among CRS and non-CSR companies with respect to profitability (ROA and ROE), market capitalization, and price of shares. However, these assessments are based on the verification data of companies from 50 countries, and research results reveal two main contributors to CSR strategy. The first is firm characteristics such as profitability. In food companies, the leverage does not impact CSR engagement so strongly due to diverse access to debt capital. The firm-specific features in CSR contribution were mostly indicated by market capitalization, which relates to firm size. Large companies have more financial resources because of the economies of scale effect [70]. The main difference in engaging the companies in CSR activities was company size. The majority of companies that promote CSR activities were from a group of larger units [11]. A similar examination for one country could not conclude a similar conclusion for CSR engagement financial characteristics worldwide. For example, the study of the Bucharest Stock Exchange examination noticed no significant difference in financial performance between CSR companies and non-CSR companies [60]. Similar results were performed for food and beverage companies from Greece. Thus, in this study, even large companies due to the economic crises do not spend money on CSR actions. In addition, according to the study of Kurilets, CSR announcements of American food companies 
do not have the impact of their stock return [71]. It was explained by the level of CSR activities attractiveness that could be evaluated by different stakeholder groups differently [72]. The lack of uniformity of research in assessing the financial situation and implementation of the CSR strategy was also confirmed by Becchetti et al. [73]. Roberts noticed a positive relation of profitability to CSR disclosure, based on the stakeholder theory of strategic management ground [74]. However, another perspective shows that less profitable companies tend to publish more information about CSR activities to gain investors' attention [75]. Berthelot et al. also confirmed this conclusion [76] and suggested that the publication of sustainability reports will benefit a company from a longer perspective.

The results suggest that CSR is affected by the efficiency of the company's financial performance (higher ROA and ROE belong to the more socially responsible firm) $[65,77]$. However, past studies explained that the food industry ignored the CSR due to the lack of short-term profit changes [16]. The long-term sustainable creation of shared value involves serving, supporting, and helping society directly as a good practice [78]. Food companies that implement the CSR strategy noticed lower risk measures that could be related to a larger group of stakeholders. Companies in the food industry that generate CSR strategies and CSR history are better prepared for crisis management [79].

The results do not underline the direction of impact financial performance of CSR implementation directly and conversely. The positive relation between CSR report publication and ROE was also noticed in other studies $[80,81]$ as one of the factor that determines higher net income in the future. According to Conway, a positive and significant effect from CSR on ROE exists $[59,64,81,82]$. It underlines the issue that more profitable firms feel the obligation to invest in CSR [17]. The results of the study also confirmed that spending on CSR does not reduce the financial performance of food companies. Trihermanto and Nainggolan also noticed similar results [62]. In other studies, the impact of ROE on market value is essential and statistically significant in every sector [83], so it is not an industry characteristic directly.

The CSR activities could enhance income and put companies in a better position to pay (higher) dividends [67]. However, this situation did not occur in the research sample, which could be related to a small number of companies that regularly paid a dividend [84].

\section{Conclusions}

In a given company, the higher the values of profitability and market capitalization, the more prone the company is to invest in its CSR engagement. However, smaller and younger companies could not have this possibility due to lower profitability and a smaller scale of performance. The CSR strategy approach shows a long-term strategy that is being implemented by companies with a more grounded position in the market. Thus, the level of CSR involvement (or the only situation in which this strategy is realized) does not reduce company income.

Based on the research results, several gaps in the literature have been identified that need to be addressed. Every company has a different range of CSR practices and its commitment to it is also quite diverse. The limitations of the study concern the unbalanced panel data. The study is also limited by not having included the effect of the companies' investment in intangible assets.

Further research should be related to the level of economic development of the country and the financial market itself in terms of the importance of information asymmetry. This issue could concern the most effective channels for information sharing to achieve the most beneficial CSR practices that have an influence on company value.

Author Contributions: Conceptualization, M.M.-S.; methodology, M.M.-S.; validation and data collection, M.M.-S.; writing—original draft preparation, M.M.-S.; writing—review and editing, J.P. and M.M.-S. All authors have read and agreed to the published version of the manuscript.

Funding: This research received no external funding.

Conflicts of Interest: The authors declare no conflict of interest. 


\section{References}

1. Wang, R.; Huang, Y. Communicating corporate social responsibility (CSR) on social media: How do message source and types of CSR messages influence stakeholders' perceptions? Corp. Commun. 2018, 23, 326-341. [CrossRef]

2. Kent, M.L.; Taylor, M. From Homo Economicus to Homo dialogicus: Rethinking social media use in CSR communication. Public Relat. Rev. 2016, 42, 60-67. [CrossRef]

3. Rhou, Y.; Singal, M.; Koh, Y. CSR and financial performance: The role of CSR awareness in the restaurant industry. Int. J. Hosp. Manag. 2016, 57, 30-39. [CrossRef]

4. Akpinar, A.; Jiang, Y.; Gómez-Mejía, L.R.; Berrone, P.; Walls, J.L. Strategic use of CSR as a signal for good management. SSRN Electron. J. 2008. [CrossRef]

5. Ratajczak, M. Knowledge of the concept of corporate social responsibility in agribusiness enterprises (based on the example of the SME sector in Malopolska). Management 2016, 20, 337-351. [CrossRef]

6. Nazzaro, C.; Stanco, M.; Marotta, G. The life cycle of corporate social responsibility in agri-food: Value creation models. Sustainability 2020, 12, 1287. [CrossRef]

7. Stawicka, E. CSR w kontekście zrównoważonego rozwoju sektora rolno-spożywczego. Tur. Rozw. Reg. 2018, 93-104. [CrossRef]

8. Tarabella, A.; Burchi, B. A Corporate Social Responsibility Multidimensional Indicator To Evaluate the Effects on Financial Performance of the Chemical Industry. Qual. Access Success 2013, 14, 102-109.

9. Maloni, M.J.; Brown, M.E. Corporate social responsibility in the supply chain: An application in the food industry. J. Bus. Ethics 2006, 68, 35-52. [CrossRef]

10. Rahdari, A.; Sheehy, B.; Khan, H.Z.; Braendle, U.; Rexhepi, G.; Sepasi, S. Exploring global retailers' corporate social responsibility performance. Heliyon 2020, 6, e04644. [CrossRef]

11. Costopoulou, C.; Ntaliani, M.; Ntalianis, F. CSR in food and beverage industry: The Greek case. In Proceedings of the 2018 9th International Conference on Information, Intelligence, Systems and Applications (IISA), Zakynthos, Greece, 23-25 July 2018; pp. 1-4. [CrossRef]

12. Del Giudice, T.; Stranieri, S.; Caracciolo, F.; Ricci, E.C.; Cembalo, L.; Banterle, A.; Cicia, G. Corporate Social Responsibility certifications influence consumer preferences and seafood market price. J. Clean. Prod. 2018, 178, 526-533. [CrossRef]

13. Lerro, M.; Vecchio, R.; Caracciolo, F.; Pascucci, S.; Cembalo, L. Consumers' heterogeneous preferences for corporate social responsibility in the food industry. Corp. Soc. Responsib. Environ. Manag. 2018, 25, 1050-1061. [CrossRef]

14. Freeman, R.E. Strategic Management: A Stakeholder Approach; Pittman: Boston, MA, USA, 1984.

15. Nelling, E.; Webb, E. Corporate social responsibility and financial performance: The "virtuous circle" revisited. Rev. Quant. Financ. Account. 2009, 32, 197-209. [CrossRef]

16. Hung, S.W.; Li, C.M.; Lee, J.M. Firm growth, business risk, and corporate social responsibility in Taiwan's food industry. Agric. Econ. 2019, 65, 366-374. [CrossRef]

17. Rexhepi, G.; Kurtishi, S.; Bexheti, G. Corporate Social Responsibility (CSR) and Innovation-The Drivers of Business Growth? Procedia Soc. Behav. Sci. 2013, 75, 532-541. [CrossRef]

18. Hui, L.T. Combining faith and CSR: A paradigm of corporate sustainability. Int. J. Soc. Econ. 2008, 35, 449-465.

19. Akisik, O.; Gal, G. Financial performance and reviews of corporate social responsibility reports. J. Manag. Control 2014, 25, 259-288. [CrossRef]

20. Reggy Hooghiemstra Corporate Communication and Impression Management- New Perspectives WHy Companies Engage in Corporate Social Reporting. J. Bus. Ethics 2000, 27, 55-68. [CrossRef]

21. Peters, R.; Mullen, R.M. Some Evidence of the Cumulative Effects of Corporate Social Responsibility on Financial Performance. J. Glob. Bus. Issues 2009, 3, 1-14. [CrossRef]

22. Suto, M.; Takehara, H. CSR and cost of capital: Evidence from Japan. Soc. Responsib. J. 2017, 13, 798-816. [CrossRef]

23. Simionescu, L.N.; Dumitrescu, D. Empirical study towards corporate social responsibility practices and company financial performance. Evidence for companies listed on the Bucharest stock exchange. Sustainability 2018, 10, 3141. [CrossRef]

24. Agarwal, S.K. Corporate Social Responsibility in India; SAGE Publications Inc.: Thousand Oaks, CA, USA, 2008. 
25. Matuszak, Ł.; Różańska, E. An examination of the relationship between CSR disclosure and financial performance: The case of Polish banks. J. Account. Manag. Inf. Syst. 2017, 16, 522-533. [CrossRef]

26. Goncharov, V.N.; Erokhin, A.M.; Ivashova, V.A.; Kolosova, O.U.; Tronina, L.A.; Kamalova, O.N. Social responsibility and professional competence of safegueard specialists for the quality and safety of food products. IOP Conf. Ser. Earth Environ. Sci. 2020, 422. [CrossRef]

27. Glavas, A.; Kelley, K. The Effects of Perceived Corporate Social Responsibility on Employee Attitudes. Bus. Ethics Q. 2014, 24, 165-202. [CrossRef]

28. Oh, S.; Hong, A.; Hwang, J. An analysis of CSR on firm financial performance in stakeholder perspectives. Sustainability 2017, 9, 1023. [CrossRef]

29. Lindgreen, A.; Swaen, V.; Johnston, W.J. Corporate social responsibility: An empirical investigation of U.S. organizations. J. Bus. Ethics 2009, 85, 303-323. [CrossRef]

30. Mughal, Y.H.; Jehangir, M.; Khan, M.; Saeed, M. Nexus between corporate social responsibility and firm's performance: A panel data approach. Int. J. Financ. Econ. 2020,1-16. [CrossRef]

31. Lech, A. Corporate social responsibility and financial performance. Theoretical and empirical aspects. Comp. Econ. Res. 2013, 16, 49-62. [CrossRef]

32. Lee, S.; Heo, C.Y. Corporate social responsibility and customer satisfaction among US publicly traded hotels and restaurants. Int. J. Hosp. Manag. 2009, 28, 635-637. [CrossRef]

33. Harjoto, M.A.; Jo, H. Legal vs. Normative CSR: Differential Impact on Analyst Dispersion, Stock Return Volatility, Cost of Capital, and Firm Value. J. Bus. Ethics 2015, 128, 1-20. [CrossRef]

34. Scholtens, B. Finance as a driver of corporate social responsibility. J. Bus. Ethics 2006, 68, 19-33. [CrossRef]

35. Arora, P.; Dharwadkar, R. Corporate governance and corporate social responsibility (CSR): The moderating roles of attainment discrepancy and organization slack. Corp. Gov. Int. Rev. 2011, 19, 136-152. [CrossRef]

36. Galant, A.; Cadez, S. Corporate social responsibility and financial performance relationship: A review of measurement approaches. Econ. Res. Istraz. 2017, 30, 676-693. [CrossRef]

37. Cheng, B.; Ioannou, I.; Serafeim, G. Corporate social responsibility and access to finance. Strateg. Manag. J. 2014, 35, 1-23. [CrossRef]

38. Yang, M.; Bento, P.; Akbar, A. Does CSR influence firm performance indicators? Evidence from Chinese pharmaceutical enterprises. Sustainability 2019, 11, 5656. [CrossRef]

39. Elsayed, K.; Paton, D. The impact of environmental performance on firm performance: Static and dynamic panel data evidence. Struct. Chang. Econ. Dyn. 2005, 16, 395-412. [CrossRef]

40. Karnani, A. The case against corporate social responsibility. Wall Str. J. 2019, 23, 1-5.

41. Sun, 1. Further evidence on the association between corporate social responsibility and financial performance. Int. J. Law Manag. 2012, 54, 472-484. [CrossRef]

42. Peloza, J. The challenge of measuring financial impacts from investments in corporate social performance. J. Manag. 2009, 35, 1518-1541. [CrossRef]

43. Margolis, J.D.; Elfenbein, H.A.; Walsh, J.P. Does it pay to be good? A meta-analysis and redirection of research on the relationship between corporate social and financial performance. Ann Arbor 2007, 1001, 48109.

44. Orlitzky, M.; Schmidt, F.L.; Rynes, S.L. Corporate social and financial performance: A meta-analysis. Organ. Stud. 2003, 24, 403-441. [CrossRef]

45. Javed, M.; Rashid, M.A.; Hussain, G.; Ali, H.Y. The effects of corporate social responsibility on corporate reputation and firm financial performance: Moderating role of responsible leadership. Corp. Soc. Responsib. Environ. Manag. 2020, 27, 1395-1409. [CrossRef]

46. Van Beurden, P.; Gössling, T. The worth of values-A literature review on the relation between corporate social and financial performance. J. Bus. Ethics 2008, 82, 407-424. [CrossRef]

47. Rodgers, W.; Choy, H.L.; Guiral, A. Do Investors Value a Firm's Commitment to Social Activities? J. Bus. Ethics 2013, 114, 607-623. [CrossRef]

48. Oeyono, J.; Samy, M.; Bampton, R. An examination of corporate social responsibility and financial performance. J. Glob. Responsib. 2011, 2, 100-112. [CrossRef]

49. Wang, Q.; Dou, J.; Jia, S. A meta-analytic review of corporate social responsibility and corporate financial performance: The moderating effect of contextual factors. Bus. Soc. 2016, 55, 1083-1121. [CrossRef]

50. Wang, H.; Choi, J.; Li, J. Too little or too much? Untangling the relationship between corporate philanthropy and firm financial performance. Organ. Sci. 2008, 19, 143-159. [CrossRef] 
51. Blanco, B.; Guillamón-Saorín, E.; Guiral, A. Do Non-socially Responsible Companies Achieve Legitimacy Through Socially Responsible Actions? The Mediating Effect of Innovation. J. Bus. Ethics 2013, 117, 67-83. [CrossRef]

52. Brammer, S.; Millington, A. Does it pay to be different? An analysis of the relationship between corporate social and financial performance. Business 2008, 29, 1325-1343. [CrossRef]

53. Surroca, J.; Tribó, J.A.; Waddock, S. Corporate responsibility and financial performance: The role of intangible resources. Strateg. Manag. J. 2010, 35, 463-490. [CrossRef]

54. Karagiorgos, T. Corporate social responsibility and financial performance: An empirical analysis on Greek companies. Eur. Res. Stud. J. 2010, 13, 85-108. [CrossRef]

55. Hunjra, A.I. Mediating role of dividend policy among its determinants and organizational financial performance. Cogent Econ. Financ. 2018, 6, 1-16. [CrossRef]

56. Franc-Dąbrowska, J.; Mądra-Sawicka, M.; Ulrichs, M. Determinants of dividend payout decisions-the case of publicly quoted food industry enterprises operating in emerging markets. Econ. Res. Istraz. 2020, 33, 1108-1129. [CrossRef]

57. Mishra, S.; Suar, D. Does Corporate Social Responsibility Influence Firm Performance of Indian Companies? J. Bus. Ethics 2010, 95, 571-601. [CrossRef]

58. Sen, S.; Bhattacharya, C.B. Does doing good always lead to doing better? Consumer reactions to corporate social responsibility. J. Mark. Res. 2001, 38, 225-243. [CrossRef]

59. Maggina, A.; Tsaklanganos, A.A. Predicting the corporate social responsibility of listed companies in Greece using market variables. J. Appl. Bus. Res. 2012, 28, 661-672. [CrossRef]

60. Dumitrescu, D.; Simionescu, L. Corporate social responsibility (CSR) and company financial performance: Empirical evidence from listed companies in Romania. In Entrepreneurship, Business and Economics; Springer: Cham, Switzerland, 2016; Volume 2, pp. 677-689. ISBN 9783319275734.

61. Withisuphakorn, P.; Jiraporn, P. The effect of firm maturity on corporate social responsibility (CSR): Do older firms invest more in CSR? Appl. Econ. Lett. 2016, 23, 298-301. [CrossRef]

62. Trihermanto, F.; Nainggolan, Y.A. Corporate life cycle, CSR, and dividend policy: Empirical evidence of Indonesian listed firms. Soc. Responsib. J. 2018, 16, 159-178. [CrossRef]

63. Tang, Z.; Hull, C.E.; Rothenberg, S. How Corporate Social Responsibility Engagement Strategy Moderates the CSR-Financial Performance Relationship. J. Manag. Stud. 2012, 49, 1274-1303. [CrossRef]

64. Iqbal, S.; Nawaz, A.; Ehsan, S. Financial performance and corporate governance in microfinance: Evidence from Asia. J. Asian Econ. 2019, 60, 1-13. [CrossRef]

65. Dewi, D.M. CSR Effect on Market and Financial Performance. El Dinar J. Keuang. Perbank. Syariah 2013, 1, 198-216. [CrossRef]

66. Benlemlih, M. Corporate social responsibility and dividend policy. Res. Int. Bus. Financ. 2019, 47, 114-138. [CrossRef]

67. Cheung, A.; Hu, M.; Schwiebert, J. Corporate social responsibility and dividend policy. Account. Financ. 2016, 58, 787-816. [CrossRef]

68. Hartmann, M. Corporate social responsibility in the food sector. Eur. Rev. Agric. Econ. 2011, 38, $297-324$. [CrossRef]

69. Kong, D. Does corporate social responsibility matter in the food industry? Evidence from a nature experiment in China. Food Policy 2012, 37, 323-334. [CrossRef]

70. Dyduch, J.; Krasodomska, J. Determinants of corporate social responsibility disclosure: An empirical study of Polish listed companies. Sustainability 2017, 9, 1934. [CrossRef]

71. Kurilets, N. Stock Market Reaction To The CSR Announcements Of American Fast Food. Master's Thesis, Lappeenranta University of Technology, Lappeenranta, Finland, 2014.

72. Shnayder, L.; Van Rijnsoever, F.J.; Hekkert, M.P. Motivations for Corporate Social Responsibility in the packaged food industry: An institutional and stakeholder management perspective. J. Clean. Prod. 2016, 122, 212-227. [CrossRef]

73. Becchetti, L.; Ciciretti, R.; Hasan, I.; Kobeissi, N. Corporate social responsibility and shareholder's value. J. Bus. Res. 2012, 65, 1628-1635. [CrossRef]

74. Roberts, R.W. Determinants of corporate social responsibility disclosure: An application of stakeholder theory. Account. Organ. Soc. 1992, 17, 595-612. [CrossRef] 
75. Ho, L.C.J.; Taylor, M.E. An empirical analysis of triple bottom-line reporting and its determinants: Evidence from the United States and Japan. J. Int. Financ. Manag. Account. 2007, 18, 123-150. [CrossRef]

76. Berthelot, S.; Coulmont, M.; Serret, V. Do Investors Value Sustainability Reports? A Canadian Study. Corp. Soc. Responsib. Environ. Manag. 2012, 19, 355-363. [CrossRef]

77. Mcguire, J.B.; Sundgren, A.; Schneeweis, T.; Mcguire, J.B. Corporate social responsibility and firm financial performance. Acad. Manag. J. 1988, 31, 854-872.

78. Wiśniewska-Paluszak, J.; Paluszak, G. Examples of Creating Shared Value (CSV) in Agribusiness in Poland. Ann. Polish Assoc. Agric. Agribus. Econ. 2019, 21, 297-306. [CrossRef]

79. Assiouras, I.; Ozgen, O.; Skourtis, G. The impact of corporate social responsibility in food industry in product-harm crises. Br. Food J. 2013, 115, 108-123. [CrossRef]

80. Dewilde, C.; Lancee, B. Income Inequality and Access to Housing in Europe. Eur. Social. Rev. 2013, 29, 1189-1200. [CrossRef]

81. Hammond, S.A.; Slocum, J.W. The impact of prior firm financial performance on subsequent corporate reputation. J. Bus. Ethics 1996, 15, 159-165. [CrossRef]

82. Conway, E. CSR, financial performance and risk: Does it add up for mid-caps? In Proceedings of the British Academy of Management Conference (BAM2017), Contribution 1003, University of Warwick, Coventry, UK, 5-7 September 2017; pp. 5-7.

83. Daszyńska-Żygadło, K.; Słoński, T.; Zawadzki, B. The market value of CSR performance across sectors. Eng. Econ. 2016, 27, 230-238. [CrossRef]

84. Brav, A.; Graham, J.; Harvey, C.; Michaely, R. Payout policy in the 21st century. J. Financ. Econ. 2005, 77, 483-527. [CrossRef]

(C) 2020 by the authors. Licensee MDPI, Basel, Switzerland. This article is an open access article distributed under the terms and conditions of the Creative Commons Attribution (CC BY) license (http://creativecommons.org/licenses/by/4.0/). 